\title{
Effect of intravenous adrenaline on electrocardiogram, blood pressure, and serum potassium
}

\author{
A D STRUTHERS, J L REID, R WHITESMITH, J C RODGER
}

From the University Department of Materia Medica, and Department of Biochemistry, Stobhill General Hospital, Glasgow, and Medical Unit, Monklands and District General Hospital, Airdrie, Lanarkshire

SUMMARY Increased catecholamines after myocardial infarction may contribute to the development of arrhythmias. We have infused adrenaline intravenously in nine normal volunteers to levels similar to those seen after myocardial infarction. Adrenaline caused an increase in systolic blood pressure, a decrease in diastolic blood pressure, and an increase in heart rate. Adrenaline also produced a decrease in $\mathrm{T}$ wave amplitude and an increase in the $\mathrm{QT}_{\mathrm{c}}$ interval. The serum potassium fell dramatically during the adrenaline infusion from a control value of $4.06 \mathrm{mmol} / 1$ to $3.22 \mathrm{mmol} / \mathrm{l}$. Hypokalaemia after myocardial infarction is associated with an increased incidence of ventricular arrhythmias. Thus, circulating adrenaline may increase the frequency of arrhythmias both directly via changes in ventricular repolarisation and indirectly via adrenaline induced hypokalaemia.

Hypokalaemia is not uncommonly observed in the acute phase of myocardial infarction ${ }^{12}$ when it is associated with serious ventricular arrhythmias. ${ }^{3} \mathrm{We}$ have found that in this circumstance hypokalaemia is transient, it resolves without potassium supplements, and it cannot be attributed solely to diuretic therapy. ${ }^{4}$ In addition, it is not the result either of haemodilution or of increased urinary excretion of potassium. As plasma catecholamine levels are increased in acute myocardial infarction 56 and intravenous adrenaline infusion in dogs can lower the serum potassium, ${ }^{7}$ we considered that the transient hypokalaemia of acute myocardial infarction might be a consequence of increased circulating catecholamines. The present study was undertaken to examine this hypothesis; the aim was to infuse adrenaline intravenously in normal subjects to the plasma levels observed in acute myocardial infarction and to investigate the effects on serum potassium and on the electrocardiogram.

\section{Subjects and methods}

Nine normal male volunteers aged 22 to 31 (mean 26) years were investigated. They were on no drug therapy. They had no symptoms or signs of cardiovascular disease and the resting electrocardiogram, chest radiograph, and serum electrolytes were normal.

Accepted for publication 7 October 1982
All subjects gave their informed consent to the investigation which had the approval of the hospital's research and ethical committee.

Subjects were investigated in the morning after a standard light breakfast. Intravenous cannulae were inserted into the antecubital veins of both arms. After an initial rest period of 90 minutes, the subjects received three consecutive 90 minute infusions (Braun Perfusor VI) of $5 \%$ dextrose containing $1 \mathrm{mg} / \mathrm{ml}$ ascorbic acid. The infusions contained, in sequence, $0,0.01$, and $0.06 \mu \mathrm{g} / \mathrm{kg}$ per min of 1-adrenaline (Antigen Ltd, Roscrea, Ireland) and the volume of dextrose delivered during each infusion period was $82.5 \mathrm{ml}$.

Blood pressure, heart rate, and the electrocardiogram were observed at 30 minute intervals for 90 minutes before and up to 120 minutes after the infusions. During each infusion, recordings were made at five minute intervals for the first 15 minutes and at 30 minute intervals thereafter. Blood pressure was measured with a semiautomatic sphygmomanometer (Bosomat). The electrocardiogram was displayed continuously on an oscilloscope and was recorded at 50 $\mathrm{mm} / \mathrm{s}$ on a polygraph (Grass Model 7D) at the intervals indicated above. The QT interval was measured from the onset of the $Q$ wave to the point where a tangent to the descending limb of the $T$ wave crossed the base-line. $\mathrm{QT}_{\mathrm{c}}$ was calculated according to the Bazett formula. 8

Blood for serum electrolytes was taken at 30 minute intervals before and after the infusion and at the 60th 
and 90th minutes of each. Samples were collected in plain glass bottles: they were allowed to stand at room temperature and were centrifuged within 30 minutes. Electrolytes were measured on a Technicon SMA 6/60 using standard methods.

Samples for plasma adrenaline were taken at the end of each infusion. They were collected into chilled heparinised tubes, centrifuged at $4^{\circ} \mathrm{C}$, and stored at $-70^{\circ} \mathrm{C}$ until assay. Assay was by the radioenzymatic method of Da Prada and Zürcher. ${ }^{9}$

\section{Results}

Plasma adrenaline levels during the $0.06 \mu \mathrm{g} / \mathrm{kg}$ per min (high dose) adrenaline infusion were 5.5 \pm 1.7 nmol. These levels are similar to the peak adrenaline levels found by Karlsberg et al. ${ }^{10}$ in their study of patients after acute myocardial infarction. As it was our aim to simulate the effects of adrenaline at the plasma levels encountered in acute myocardial infarction, only the findings during the control and high dose infusion are considered in detail in this report. The results during the control infusion and during the high dose infusion have been compared by paired $t$ test.

\section{HAEMODYNAMIC EFFECTS}

The mean of the observations at the 30th, 60th, and 90th minutes of the control and high dose infusion have been compared. The haemodynamic responses to infused adrenaline were as expected, with an increase in both heart rate $(+7 \pm 9$ beats $/ \mathrm{min} ; \mathrm{p}<0.05)$ and systolic blood pressure $(+11 \pm 6 \mathrm{mmHg}$; $\mathrm{p}<0.001)$ and a decrease in diastolic blood pressure $(-14 \pm 9 \mathrm{mmHg} ; \mathrm{p}<0.002)$.

\section{SERUM POTASSIUM (Fig. 1)}

The mean of the values after 60 and 90 minutes of each infusion have been compared. The low dose infusion produced a small $(p<0.05)$ drop in serum potassium. During the high dose infusion, serum potassium for the group fell from $4.06 \pm 0.14$ to $3.22 \pm 0.26 \mathrm{mmol} / 1(p<0.0001) ; 90$ minutes after stopping the infusion, the serum potassium had returned to baseline.

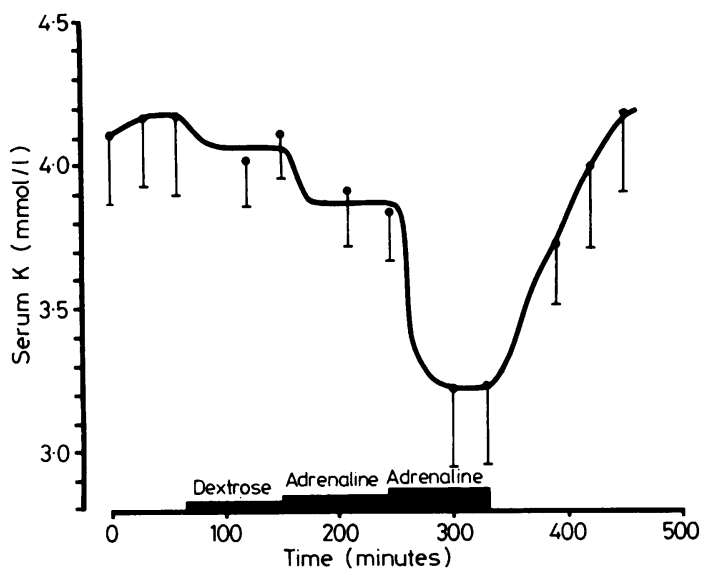

Fig. 1 Changes in serum potassium (mean $\pm 1 S D$ ) produced by infusion of $5 \%$ dextrose containing $0,0.01$, and $0.06 \mu \mathrm{g} / \mathrm{kg}$ per min adrenaline in nine normal subjects.
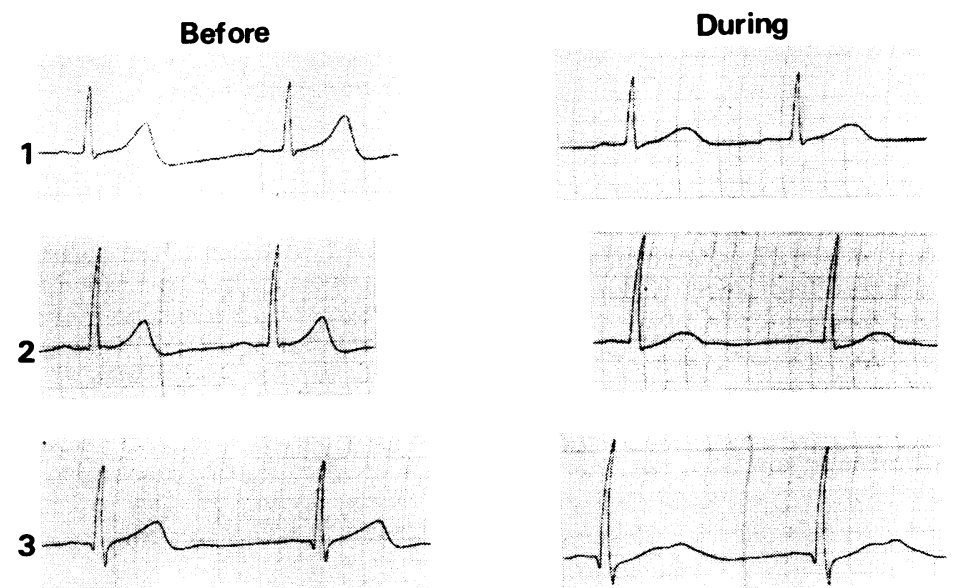

Fig. 2 Single lead electrocardiogram $(50 \mathrm{~mm} / \mathrm{s}$ ) before infusion and during the $0.06 \mu \mathrm{g} / \mathrm{kg}$ per min adrenaline infusion in three normal subjects. Infusion produces decreased $T$ wave amplitude, $U$ waves (case 3), ST segment displacement (cases 2 and 3) and $Q T$ prolongation. (QT increases from $0.37 \mathrm{~s}$ to $0.41 \mathrm{~s}$ in case 1 and from $0.32 \mathrm{~s}$ to $0.36 \mathrm{~s}$ in case 2.) 
ELECTROCARDIOGRAM (Fig. 2)

All subjects remained in stable sinus rhythm throughout the infusions.

\section{$T$ waves}

The findings at the 90th minute of each infusion have been compared. With the high dose infusion, $T$ wave amplitude decreased in eight subjects and increased in one; the mean decrease for the group was $-2.5 \pm 1.9$ $\mathrm{mm}(\mathrm{p}<0.002)$. With the low dose infusion, $\mathrm{T}$ wave amplitude decreased in five subjects; the mean decrease for the group was $-0.61 \pm 0.86 \mathrm{~mm}$ $(\mathrm{p}<0.05)$.

\section{$U$ waves}

Three subjects developed $U$ waves during the high dose adrenaline infusion; no $U$ waves developed during the low dose infusion.

\section{$Q T$ interval}

The findings at the 90th minute of each infusion have been compared. The low dose infusion increased the QT interval in five subjects; for the group, QT increased from $0.36 \pm 0.02 \mathrm{~s}$ to $0.37 \pm 0.03 \mathrm{~s}(\mathrm{p}<0.05)$. With the high dose infusion, the QT interval increased in eight subjects and was unchanged in one; for the group, QT increased from $0.36 \pm 0.02 \mathrm{~s}$ to $0.40 \pm 0.05 \mathrm{~s}(\mathrm{p}<0.01)$. The heart rate corrected QT interval $\left(\mathrm{QT}_{\mathrm{c}}\right)$ was also increased by the high dose infusion; for the group, the $\mathrm{QT}_{\mathrm{c}}$ increased from $0.36 \pm 0.02 s$ to $0.41 \pm 0.06 s(p<0.01)$.

\section{ST segments}

With the high dose infusion, minor upward-sloping ST segment depression developed in three subjects. No ST segment displacement was noted during the low dose infusion.

\section{Discussion}

Adrenaline infused into animals ${ }^{711}$ and, in high dose, to man ${ }^{12}$ causes a decrease in serum potassium. The effect is thought to be the result of stimulation of a beta ${ }_{2}$ adrenoceptor linked to $\mathrm{Na}^{+} / \mathrm{K}^{+}$ATPase. This adrenaline induced potassium influx has been shown both in human erythrocytes and in rat skeletal muscle. ${ }^{13} 14$ Our study shows that the levels of adrenaline found after acute myocardial infarction can cause significant hypokalaemia in normal subjects and that this adrenaline-induced hypokalaemia develops rapidly and resolves relatively quickly. These findings support our previous suggestion that the transient hypokalaemia observed during the acute phase of myocardial infarction may be the result of increased circulating catecholamines. ${ }^{4}$

Lepeschkin et al. ${ }^{15}$ examined the effects of infused adrenaline $(0.1$ and $0.3 \mu \mathrm{g} / \mathrm{kg}$ per $\mathrm{min})$ on the electrocardiogram of normal subjects. They did not look for changes in the QT interval, but, as in the present study, they did observe $U$ waves, a decrease in $T$ wave amplitude, and displacement of the ST segment. Abildskov ${ }^{16}$ studied the effect of infused adrenaline on the QT interval of dogs. He found that this was prolonged by rapid injection but shortened by slow infusion of adrenaline.

This study has shown that the levels of plasma adrenaline observed in acute myocardial infarction can in normal subjects produce changes in ventricular repolarisation which are reflected in $\mathrm{T}$ wave flattening and QT prolongation. Though our subjects remained in sinus rhythm, these adrenaline induced abnormalities of repolarisation could, in theory, predispose to arrhythmias. ${ }^{17}$ Prolongation of the QT in particular may be relevant to the genesis of arrhythmias during the acute phase of myocardial infarction. ${ }^{18}$

It has been suggested that $\mathrm{T}$ wave flattening and ST segment displacement in asymptomatic men with unobstructed coronary arteries are the result of increased sympathetic activity and our results are in line with this. ${ }^{1920}$ The electrocardiographic changes which we have observed may therefore be mediated directly by the effects of adrenaline on beta adrenoceptors, by the hypokalaemia induced by adrenaline or by a combination of both.

The importance of the sympathetic nervous system in the genesis of postmyocardial infarction arrhythmias remains controversial. ${ }^{21}$ Our study, however, suggests that circulating plasma catecholamines especially adrenaline could have a role to play in the production of these arrhythmias. The underlying mechanism may be not only direct via beta adrenoceptor stimulation but also indirect via adrenaline induced hypokalaemia.

\section{References}

1 Dyckner T, Helmers C, Lundman T, Wester PO. Initial serum potassium level in relation to early complications and prognosis in patients with acute myocardial infarction. Acta Med Scand 1975; 197: 207-10.

2 Solomon R, Cole A. In: Wood C, Somerville W, eds. Arrhythmias and myocardial infarction: the role of potassium. London: R.S.M. and Academic Press, 1981: 12. (Roy Soc Med Int Congress and Symposium Series, 44.)

3 Donnelly T, Gray H, Simpson E, Rodger JC. Serum potassium in acute myocardial infarction (abstract). Scott Med f 1980; 25: 176.

4 Rolton H, Simpson E, Donnelly T, Rodger JC. Plasma potassium in acute myocardial infarction. Eur Heart $\mathcal{F}$ 1981: 2, suppl A: 21 .

5 Videbaek J, Christensen NJ, Sterndorff B. Serial determination of plasma catecholamines in myocardial infarction. Circulation 1972; 46: 846-55. 
6 Vetter NJ, Strange RC, Adams W, Oliver MF. Initial metabolic and hormonal response to acute myocardial infarction. Lancet 1974; i: 284-9.

7 Grassi AO, de Lew MF, Cingolani HE, Blesa ES. Adrenergic beta blockade and changes in plasma potassium following epinephrine administration. Eur $\mathfrak{f}$ Pharmacol 1971; 15: 209-13.

8 Bazett HC. An analysis of the time-relations of electrocardiograms. Heart 1920; 7: 353-70.

9 Da Prada M, Zürcher G. Simultaneous radioenzymatic determination of plasma and tissue adrenaline, noradrenaline and dopamine within the femtomole range. Life Sci 1976; 19: 1161-74.

10 Karlsberg RP, Cryer PE, Roberts R. Early adrenergic response to myocardial infarction: relation to myocardial damage and late mortality (abstract). Clin Res 1979; 27: 178A.

11 D'Silva JL. The action of adrenaline on serum potassium. $\mathcal{F}$ Physiol (Lond) 1934; 82: 393-8.

12 Messara F, Tripodina A, Rotunno M. Propranolol block of epinephrine-induced hypokalaemia in man. Eur $\mathfrak{f}$ Pharmacol 1970; 10: 404-7.

13 Clausen T, Flatman JA. $\beta_{2}$-Adrenoceptors mediate the stimulating effect of adrenaline on active electrogenic $\mathrm{Na}-\mathrm{K}$-transport in rat soleus muscle. $\mathrm{Br} \mathcal{F}$ Pharmacol 1980; 68: 749-55.

14 Bodemann HH, Irmer M, Schlutter K. Catecholamines stimulate the $\mathrm{Na}, \mathrm{K}$-pump of human erythrocytes in vivo. Proceedings 16th Annual Meeting of European Society of Clinical Investigation. 1982; abstract No. 23.
15 Lepeschkin E, Marchet H, Schroeder G, et al. Effect of epinephrine and norepinephrine on the electrocardiogram of 100 normal subjects. Am $\mathcal{F}$ Cardiol 1960; 5: 594-603.

16 Abildskov JA. Adrenergic effects on the QT interval of the electrocardiogram. Am Heart $\mathcal{F}$ 1976; 92: 210-6.

17 Vincent GM, Abildskov JA, Burgess MJ. Q-T interval syndromes. Prog Cardiovasc Dis 1974; 16: 523-30.

18 Doroghazi RM, Childers R. Time-related changes in the Q-T interval in acute myocardial infarction: possible relation to local hypocalcemia. Am $\mathcal{F}$ Cardiol 1978; 41: 684-8.

19 Atterhög JH, Eliasson K, Hjemdahl P. Sympathoadrenal and cardiovascular responses to mental stress, isometric handgrip, and cold pressor test in asymptomatic young men with primary $\mathrm{T}$ wave abnormalities in the electrocardiogram. Br Heart f 1981; 46: 311-9.

20 Taggart P, Donaldson R, Green J, et al. Interrelation of heart rate and autonomic activity in asymptomatic men with unobstructed coronary arteries. Studies with atrial pacing, adrenaline infusion, and autonomic blockade. $\mathrm{Br}$ Heart $\mathcal{F} 1982$; 47: 19-25.

21 Corr PB, Gillis RA. Autonomic neural influences on the dysrhythmias resulting from myocardial infarction. Circ Res 1978; 43: 1-9.

Requests for reprints to Dr A D Struthers, Department of Clinical Pharmacology, Royal Postgraduate Medical School, London W12 0HS. 